\title{
PROCRASTINATION AND SELF-CONCEPT IN MORE/LESS CONSCIENTIOUS STUDENTS
}

\author{
Marianna Berinšterová, Miroslava Bozogáňová, Monika Magdová, Jana Kapová, \\ \& Katarína Fuchsová \\ University of Prešov in Prešov, Faculty of Humanities and Natural Sciences, Institute of Pedagogy, \\ Andragogy and Psychology (Slovakia)
}

\begin{abstract}
Given its significant negative consequences for university students, procrastination has been studied extensively and shown to be associated with conscientiousness as a personality trait. Involving 333 university students doing teacher training programmes $(68.5 \%$ female; Mage $=20.51(\mathrm{SD}=1.61) ; 83.48 \%$ undergraduates doing a bachelor's degree), our study aimed to explore the association between procrastination among more/less conscientious students and selected self-concept variables (self-control, self-efficacy, etc.). Our questionnaire was based on the Ten-Item Personality Inventory (Gosling, Rentfrow, Swann, 2003), the Self-Control Scale (Finkenauer, Engels, Baumeister, 2005), the Self-efficacy Scale (Kočš, Hefteyova, Schwarzer, Jerusalem, 1993), and the Procrastination Scale for Student Populations (Gabrhelík, 2008); our control variables were gender and well- being (Subjective Well-Being Scale, Chan-Hoong, Soon, 2011). The sample was divided into two groups - (1) less conscientious and (2) more conscientious) - using the method of visual binning in SPSS 20. A t-test for independent samples and linear regression were used for data analysis. The less conscientious students in our sample reported a higher level of procrastination ( $\mathrm{t}=6.479 ; \mathrm{df}=310 ; \mathrm{p}<0.001$; Cohen's $\mathrm{d}=0.681$ ). A linear model was conducted for both groups (the dependent variable being the level of procrastination, the independent variables being gender and the levels of self-control, self-efficacy, and well-being). Both models were significant ((1) F=8.449; $\mathrm{p}<0.001 ; \mathrm{R} 2=32.6$; (2) $\mathrm{F}=7.277 ; \mathrm{p}<0.001 ; \mathrm{R} 2=25.7$ ). Among the less conscientious students, the levels of self-control $(\beta=-0.546 ; t=-5.262 ; p<0.001)$ and self-efficacy $(\beta=-0.238 ; t=-2.092 ; p<0.001)$ were negatively associated with procrastination. Among the more conscientious students, the level of self-control $(\beta=0.404$; $\mathrm{t}=-3.929 ; \mathrm{p}<0.001)$ was negatively associated with procrastination and "being a man" $(0-$ man; 1 -woman $)$ $(\beta=-0.307 ; t=-3.219 ; p<0.05)$ was significantly associated with the level of procrastination. The results of our study show trait and personality differences in the level of procrastination, highlighting the importance of self-control and self-efficacy development among university students. Interactive programmes with an impact on students' self-concept can be a significant contribution to students' ability to cope with their study requirements effectively. It could be argued that the limits of this study include cross-sectional and self-reported data.
\end{abstract}

Keywords: Procrastination, self-efficacy, self-control, university students, trait conscientiousness.

\section{Introduction}

Research into procrastination has recently attracted a lot of attention because the phenomenon is associated with serious negative consequences, typically expressed in study- and work-related performance and, subsequently, manifested through a lack of adequate satisfaction. Procrastination can be defined as a pathological, intentional, undesirable, and pointless habit, typically characterised by a tendency to delay the beginning or completion of inevitable tasks until later, associated with unpleasant conditions (anxiety, depression, shame, guilt, etc.), and representing an obstacle to goal achievement (Abbasi, Alghamdi 2015; Brownlow, Reainger 2012; Deepti, Muktiashupragya, Trapti 2017; Grunová 2015). In lay terms, procrastination is synonymous to putting off, hesitation, and laziness. Notwithstanding the fact that several scholars refer to procrastination as a purposeful strategy (Schraw, Wadkins, \& Olafson, 2007), the notion is dealt with as a negative phenomenon herein.

It has been pointed out that procrastination in the sphere of university life is associated with unsatisfactory results, stress, and anxiety (Grunová 2015), low performance when it comes to completing study-related assignments (Hussain, Sultan 2010 in Khan et al. 2014), and a low level of autoregulation in 
learning (Hussain, Sultan, according to Khan et al., 2014; Van Eerde, 2003). It is this particular kind of procrastination observable in university students that the present study focuses on.

Recent research has looked into procrastination predictors such as personality characteristics, sociodemographic variables, and environmental factors. As for gender differences, findings vary considerably. It has been revealed that men tend to procrastinate more than women (Grunová, 2015; Khan et al., 2014); other authors suggest, however, that it is women who procrastinate more often (Rodarte-Luna, \& Sherry in Khan et al., 2014). As far as personality traits are concerned, recent research has focused on the correlation between procrastination and the Big Five. For example, several studies suggest a negative relationship between procrastination and conscientiousness (Schweigerová, Slavkovská 2015; Steel, Ferrari 2013 in Abbasi, Alghamdi 2015; Steel, Klingsieck, 2016). When seen as a form of emotional regulation, procrastination brings about a conflict between present and future selves (Pychyl, Sirois, 2016), which is ultimately reflected in the individual's wellbeing.

The association between procrastination and self-concept has been studied, for example, with regard to self-regulatory mechanisms. Negative correlations have been detected not only in relation to self-control as an ability to delay gratification (Schweigerová, Slavkovská 2015), but also in relation to the more general notion of self-regulation (Dunn 2014). As for other personality factors, again, there are conflicting findings. While some researchers point out there is no correlation between procrastination and self-efficacy (Cerino 2014), others have detected a negative correlation between the two (Schweigerová, Slavkovská 2015; Malkoç, Mutlu 2018).

Procrastination predictors have been studied in relation to relatively stable personality traits, but also in relation to situational variables. In our research, we studied the rates of procrastination in two groups of students: those who are conscientious and those who are less so. We focused on students doing teacher training programmes in particular because procrastination and stress are common predictors of professional and personal burnout (Montgomery \& Rupp, 2005; Skaalvik \& Skaalvik, 2009); given the nature of their work, teachers run a higher risk of developing the condition and, therefore, a higher level of self-regulation seems all the more desirable in this target group.

\section{Research objectives}

This study aimed to explore the association between selected self-concept variables (self-control, self-efficacy) and procrastination among more/less conscientious students.

\section{Research sample and data collection}

The research involved 333 university students doing teacher training programmes at Prešov University, $68.5 \%$ of them being female $(n=228)$ and 30.6 male $(n=102)$, aged between 17 and 27 $(\mathrm{M}=20.51 ; \mathrm{SD}=1.61)$. The data collection process was anonymous and each questionnaire included a unique code.

\section{Methods} and age.

The study included two items pertaining to the sphere of sociodemographic factors, namely gender

With regard to personality traits, we focused on the following variables in particular:

- The only Big-Five factor included in the present study was conscientiousness, which we mapped using a TIPI questionnaire (Ten Item Personality Inventory; Gosling, Rentfrow, Swann, 2003).

- Self-efficacy was studied using the Generalized Self-Efficacy Scale (Košč et al., 1993).

- Self-control was measured using the Brief Self-Control Scale (Finkenauer, Engels, Baumeister, 2005).

- Subjective well-being was studied using the Subjective Well-Being Scale (Chan-Hoong, Soon, 2011).

- Finally, procrastination as a dependent variable was measured using the Lay's Procrastination Scale for Student Populations (Gabrhelík, 2008; Gabrhelík, Vacek, Miovský, 2006).

\section{Results}

Our research involved differential statistics and a linear model for more conscientious and less conscientious students. The T-tests results for 2 independent samples (Table 1) showed that less conscientious students had a higher rate of procrastination. 
Table 1. Differences in the levels of procrastination between less conscientious and more conscientious students.

\begin{tabular}{c|c|c|c|c|c|c|c|c} 
conscientiousness & $\mathrm{N}$ & Mean & $\mathrm{SD}$ & $\mathrm{F}$ & $\mathrm{t}$ & $\mathrm{df}$ & $\mathrm{p}$ & Cohen's d \\
\cline { 1 - 3 } \cline { 1 - 3 } less & 158 & 61.360 & 10.02 & \multirow{2}{*}{4.679} & 6.497 & 310 & 0 & 0.681
\end{tabular}

\subsection{Linear model of procrastination}

The linear model for less conscientious students was significant $(F=8.449 ; \mathrm{p}<0.001)$, accounting for $32.6 \%$ of the total variation of the dependent variable. Both self-control and self-efficacy were negatively associated with the students' level of procrastination. Controlled variables did not contribute to the model significantly.

Table 2. Linear model of procrastination for less conscientious students.

\begin{tabular}{c|c|c|c|c|c} 
& $\mathrm{B}$ & $\mathrm{SE}$ & Beta & $\mathrm{t}$ & sig \\
\hline self-control & $\mathbf{- 0 . 7 6 8}$ & $\mathbf{0 . 1 4 6}$ & $\mathbf{- 0 . 5 4 6}$ & $\mathbf{- 5 . 2 6 2}$ & $<\mathbf{0 . 0 0 1}$ \\
\hline self-efficacy & $\mathbf{- 0 . 4 8 6}$ & $\mathbf{0 . 2 3 2}$ & $\mathbf{- 0 . 2 3 8}$ & $\mathbf{- 2 . 0 9 2}$ & $\mathbf{0 , 0 4 0}$ \\
\hline well-being & 0.270 & 0.276 & 0.114 & 0.980 & 0.330 \\
\hline sex & -1.515 & 1.904 & -0.082 & -0.796 & 0.429
\end{tabular}

The linear model for more conscientious students was significant $(F=7.277 ; \mathrm{p}<0.001)$, accounting for $25.7 \%$ of the total variation of the dependent variable. Self-control was negatively associated with the students' level of procrastination. In contrast to the model for less conscientious students, the level of procrastination was not predicted through self-efficacy significantly. As for our controlled variables, sex (male) - but not well-being - was significantly associated with the model.

Table 3. Linear model of procrastination for more conscientious students.

\begin{tabular}{c|c|c|c|c|c} 
& $\mathrm{B}$ & $\mathrm{SE}$ & Beta & $\mathrm{t}$ & sig \\
\hline self-control & $\mathbf{- 0 . 8 6 4}$ & $\mathbf{0 . 2 2}$ & $\mathbf{- 0 . 4 0 4}$ & $\mathbf{- 3 . 9 2 9}$ & $\mathbf{0 . 0 0 1}$ \\
\hline self-efficacy & -0.022 & 0.281 & -0.009 & -0.079 & 0.937 \\
\hline well-being & -0.328 & 0.353 & -0.094 & -0.931 & 0.354 \\
\hline sex & $\mathbf{- 7 . 9 3 5}$ & $\mathbf{2 . 4 6 6}$ & $\mathbf{- 0 . 3 0 7}$ & $\mathbf{- 3 . 2 1 9}$ & $\mathbf{0 . 0 0 2}$
\end{tabular}

\section{Discussion and conclusions}

The research presented here focused on selected self-concept elements (self-control and self-efficacy) in relation to procrastination, the target sample being two groups of university students characterised by two different levels of conscientiousness. Our decision to use conscientiousness as a differentiating criterion was led by the fact that many authors consider this variable to be a significant predictor - negatively associated with procrastination (Kőverová, 2017; Abbasi, Alghamdi, 2015; Lee, 2005; Schweigerová, Slavkovská, 2015; Khan et al., 2014; Johnson et al., 1995). Our research shows that less conscientious students generally manifest a higher rate of procrastination - as corroborated by findings presented in a number of previous studies. In this connexion, Hřebíčková (2003) states that conscientious individuals are generally purposeful and ambitious, manifesting a high rate of self-discipline. If academic procrastination correlates with such characteristics negatively, it can be assumed that individuals who are highly prone to procrastinate manifest lower levels of self-control or self-efficacy.

Significant association with procrastination was detected in both our student groups with regard to self-control. University students with a higher level of self-control manifest a lower level of procrastination, which is in accordance with Schweigerová and Slavkovská's (2015) findings. Students' self-control can also be developed during their university study through specialised psychological training designed to help them cope with their difficulty concentrating, develop higher levels of perseverance, emotional intelligence, assertiveness, and self-control, handle disruptive influences, etc. Developing study habits (Duckworth, Taxer, Eskreis-Winkler, Galla, Gross, 2019) that eliminate study-related disruptive influences can be instrumental in developing and strengthening students' self-control, too.

In the linear models tested in our research, different research results were detected with regard to the association between procrastination and self-efficacy. Self-efficacy only proved to be a significant predictor of procrastination in the less conscientious group of students. For the sake of comparison, previous 
research had revealed that conscientiousness - which can also be defined as goal-oriented behaviour, compliance with socially determined expectations, controlling one's impulses, or being able to plan one's actions (Roberts, Jackson, Fayard, Edmonds \& Meints, 2009) - correlates with better academic performance, self-efficacy playing the role of a mediator in the relationship (Conrad, Patry, 2012). Our findings therefore suggest there is potential room for mediation analysis and studying self-efficacy as a mediator in the relationship between conscientiousness and procrastination.

The linear models of this study included two controlled variables, namely well-being and gender. While well-being did not prove to be significantly associated with procrastination in either model, gender as a significant predictor of procrastination was detected in the more conscientious group. More precisely, male gender was positively associated with procrastination-prone behaviour, which can be corroborated by at least a couple of facts: men differ from women in terms of their personality traits, including conscientiousness (Feyter et al. 2012; Karwowski et al., 2013); and gender plays the role of a mediator in the relationship between personality traits and procrastination (Nadeem et al., 2016). Moderation analysis based on "structural equation modelling" might therefore be a potential direction for further research.

Our research results can be practically applied in intervention programmes designed to support undergraduates' self-control, self-efficacy, and conscientiousness. Although conscientiousness is generally regarded to be a stable personality trait, if you consider the definition of conscientiousness used in the methodology employed in our research, conscientiousness is essentially a combination of responsibility, motivation, and perseverance - i.e., qualities that can be directly influenced. In this connexion, Steel and Klingsieck (2016) point out that any advisory intervention designed to eliminate procrastination should be focused on conscientiousness as a personality trait.

Research studies suggest that interpersonal experience and social roles shape personality traits, making the individual think, feel, and act in a specific way (Lodi-Smith and Roberts, 2007, Roberts and Wood, 2006). The normative influence of desirable or required behaviour in small or large social groups can be an instrument of social control that shapes students' conscientiousness. Most training programmes focused on self-control are carried out in adolescence - a period that is neurologically well-suited for shaping the individual's ability to control their impulses and delaying gratification until later. However, research suggests that, when it comes to self-control, nervous system maturation is by no means the only factor at play and self-control is expressed through a variety of individual personality traits (Romer, Duckworth, Sznitman, Park, 2010) that can be cultivated in later stages of life.

\section{References}

Abbasi, I. S., Alghamdi, N. G. (2015): The prevalence, predictors, causes, treatments, and implications of procrastination behaviors in general, academic, and work setting. International journal of psychological studies, 7(1), 59-66.

Bolkan, S., Goodboy, A. K. (2011): Behavioral indicators of transformational leadership in the college classroom.

Bolkan, S., Goodboy, A. K., Griffin, D. J. (2011): Teacher leadership and intellectual stimulation: Improving students' approaches to studying through intrinsic motivation. Communication research reports, 28, 337-346.

Brownlow, S., Reasinger, R. D. (2012): Putting off until tomorrow what is better done today: academic procrastination as a function of motivation toward college work. Journal of social behavior and personality, 15(5), 15-34.

Cerino, E. S. (2014): Relationships between academic motivation, self-efficacy, and academic procrastination. Journal of psychological research, 19(4), 156- 163.

Chan Hoong, L., \& Soon, D. A. (2011). Study of Emigration Attitudes of Young Singaporeans. Singapore: Institute of Policy Studies, National University of Singapore. Available at http://lkyspp.nus.edu.sg/wp-content/uploads/2013/06/wp19.pdf

Conrad, N., \& Patry, M. W. (2012). Conscientiousness and academic performance: A mediational analysis. International Journal for the Scholarship of Teaching and Learning, 6(1), n1.

De Feyter, T., Caers, R., Vigna, C., \& Berings, D. (2012). Unravelling the impact of the Big Five personality traits on academic performance: The moderating and mediating effects of self-efficacy and academic motivation. Learning and individual Differences, 22(4), 439-448.

Deepti, S., Muktiashupragya, S., Trapti, S. (2017): Procrastination versus planned procrastination - A study report. International Journal of Humanities and Social Sciences. 6(5), 1-12.

Duckworth, A. L., Taxer, J. L., Eskreis-Winkler, L., Galla, B. M., \& Gross, J. J. (2019). Self-control and academic achievement. Annual Review of Psychology, 70, 373-399.

Dunn, K. (2014): Why wait? The influence of academic self-regulation, intrinsic motivation, and statistics anxiety on procrastination in online statistics. Innovative Higher Education, 39, 33-44. 
Finkenauer, C., Engels, R. C. M. E., Baumeister, R. F. (2005): Parenting behavior andadolescent behavioural and emotional problems: The role of self-control. International Journal of Behavioral Development, 29, 58-69.

Gabrhelík, R. (2008): Akademická prokrastinace: Ověření sebeposuzovací škály, prevalence a příčiny prokrastinace. [Vyhl'adané na http://is.muni.cz/th/114738/fss_d/Proc_disertace_gab.pdf]

Gabrhelík, R., Vacek, J., Miovský, M. (2006): Prokrastinace: Validizace sebeposuzovací škály na populaci studentů vysokých škol. Československá psychologie, 50(4), 361-371.

Gosling, S. D., Rentrow, P. J., Swann, W. B., Jr. (2003): A very brief measure of the Big-Five personality domains. Journal of Research in Personality, 37, 504-528.

Grunová, M. (2015): Akademická prokrastinace a její negativní dopady na vysokoškolské studenty. Pedagogika.sk, 6(4), 261-280.

Hřebíčková, M. (2011): Pětifaktorový model v psychologii osobnosti. Praha, Grada Publishing.

Johnson, J. L. (1995): An analysis of the contribution of the five factors of personality to variance in academic procrastination. Personality an Individual Differences, 18(1), 70-87.

Karwowski, M., Lebuda, I., Wisniewska, E., \& Gralewski, J. (2013). Big five personality traits as the predictors of creative self-efficacy and creative personal identity: Does gender matter?. The Journal of Creative Behavior, 47(3), 215-232.

Khan, M. J., Arif, H., Noor, S. S., Muneer, S. (2014). Academic procrastination among male and female university and college students. Journal of Social Sciences, 8(2), 65-70.

Košč, M., Heftyová, E., Schwarzer, R., Jerusalem, M. (1993): Slovakian Adaptation of the General Self- Efficacy Scale. [Available at http://userpage.fu- berlin.de/ health/slovak.htm]

Köverová, N. (2017): Demografické, osobnostné a motivačné prediktory prokrastinácie u stredoškolských študentov. In: Maierová, E., Viktorová, L., Suchá, J., Dolejš, M. (Eds.), PhD. Existence 2017: Sborník odborných příspěvků. Olomouc, Univerzita Palackého v Olomouci, 46-57.

Lee, E. (2005): The relationship of motivation and flow experience to academic procrastination in university students. The journal of genetic psychlology, 166(1), 5-14.

Lodi-Smith, J., Roberts, B.W. (2007): Social investment and personality: A meta-analysis of the relationship of personality traits to investment in work, family, religion, and volunteerism. Personality and social psychology review, 11, 68-86.

Malkoç, A., Mutlu, A. K. (2018): Academic self-efficacy and academic procrastination: Exploring the mediating role of academic motivation in Turkish university students. Universal journal of educational research, 6(10), 2087-2093.

Montgomery, C., \& Rupp, A. A. (2005). A meta-analysis for exploring the diverse causes and effects of stress in teachers. Canadian Journal of Education/Revue canadienne de l'éducation, 458-486.

Nadeem, M., Malik, A. A., \& Javaid, F. (2016). Link between personality traits and procrastination among university students. Journal of educational research, 19(2), 92.

Pychyl, T. A., \& Sirois, F. M. (2016). Procrastination, emotion regulation, and well-being. In Procrastination, health, and well-being (pp. 163-188). Academic Press.

Qualitative research reports in communication, 12(1), 10-18.

Roberts, B. W., Jackson, J. J., Fayard, J. V., Edmonds, G., \& Meints, J. (2009). Conscientiousness. In M. R. Leary \& R. H. Hoyle (Eds.), Handbook of individual differences in social behavior (p. 369-381). The Guilford Press.

Roberts, B. W., Wood, D. (2006): Personality development in the context of the neo-socioanalytic model of personality. In: Mroczek, D. K., Little, T. D. (Eds.), Handbook of personality development. New Jersey, Lawrence Erlbaum Associates, 11-39.

Romer, D., Duckworth, A. L., Sznitman, S., Park, S. (2010): Can adolescents learn self-control? Delay of gratification in the development of control over risk taking. Prevention science, 11(3), 319-330.

Schraw, G., Wadkins, T., \& Olafson, L. (2007). Doing the things we do: A grounded theory of academic procrastination. Journal of Educational psychology, 99(1), 12.

Schweigerová, K., Slavkovská, M. (2015): Akademická prokrastinácia v kontexte exekutívnych funkcií. E psychologie, 9(2), $26-35$.

Skaalvik, E. M., \& Skaalvik, S. (2009). Does school context matter? Relations with teacher burnout and job satisfaction. Teaching and teacher education, 25(3), 518-524.

Steel, P., \& Ferrari, J. (2013). Sex, education and procrastination: An epidemiological study of procrastinators' characteristics from a global sample. European Journal of Personality, 27(1), 51-58.

Steel, P., \& Klingsieck, K. B. (2016). Academic procrastination: Psychological antecedents revisited. Australian Psychologist, 51(1), 36-46.

van Eerde, W. (2003). A Meta-Analytically Derived Nomological Network of Procrastination. Personality and Individual Differences, 35, 1401-1418. 